\title{
Societal uncertainties recognised in recent nuclear and radiological emergencies
}

\author{
Y. Tomkiv ${ }^{1, *}$, T. Perko ${ }^{2}$, R. Sala ${ }^{3}$, N. Zeleznik ${ }^{4}$, M. Maitre ${ }^{5}$, T. Schneider ${ }^{5}$ and D.H. Oughton ${ }^{1}$ \\ ${ }^{1}$ NMBU/CERAD - Norwegian University of Life Sciences, Centre for Environmental Radioactivity, Ås, Norway. \\ 2 SCK-CEN-Belgian Nuclear Research Centre, Mol, Belgium. \\ ${ }^{3}$ CIEMAT-CISOT - Sociotechnical Research Centre, Barcelona, Spain. \\ ${ }^{4}$ EIMV-Elektroinštitut Milan Vidmar, Ljubljana, Slovenia. \\ ${ }^{5}$ CEPN-Centre d'étude sur l'Évaluation de la Protection dans le domaine Nucléaire, Fontenay-aux-Roses, France.
}

\begin{abstract}
The paper aims to stimulate reflection and debate on the issue of uncertainty as a key component of nuclear or radiological emergency management. It identifies and discusses different types of uncertainties that appeared during and after real emergencies. For this, seven different case studies of nuclear and radiological events have been analysed using three separate methodological approaches: i) case descriptions (document review); ii) media analysis; and iii) semi-structured interviews. The overall objective was to elucidate the understanding and response to scientific and social uncertainties, and related ethical issues. A range of different uncertainties were identified and roughly grouped into categories related to: 1) technical and measurement uncertainties; 2) societal impacts and societal framing; 3) contradictory information and communication aspects; 4) ethical aspects. This analysis intends to inform emergency managers on the types of uncertainties that may appear to different actors during nuclear or radiological emergency. The results should serve to stimulate preparation on the uncertainty response and by this also to reduce some of the identified uncertainties.
\end{abstract}

Keywords: social uncertainties / decisions / citizens / emergency / ethics / CONFIDENCE

\section{Introduction}

Nuclear and radiological emergencies are inherently very complex; they are urgent, full of contingencies (Leonard and Howitt, 2008), unanticipated, dynamic and unpredictable (Schmid, 2013; Charron et al., 2016), involve a great number of actors and experts (Marignac et al., 2016) and influence economic, social and cultural life of people (Felt and Chhem, 2016). Because of these aspects, emergency and post-accident situations are affected by a variety of uncertainties that complicate decision-making and weaken effective emergency management processes.

There is a need to identify, analyse and develop approaches to manage these uncertainties in order to improve decisionmaking in nuclear and radiological emergencies. This research focused on social, ethical and communicational aspects of uncertainty management, which have not yet been addressed in a structured and multi-disciplinary way (Turcanu et al., 2020).

This paper presents an analysis of seven different case studies of nuclear and radiological events that took place in or affected different European countries (Halden 2016, Norway;

*Corresponding author: yevgeniya.tomkiv@nmbu.no
IRE-Fleurus 2008, Belgium; Asco 1, 2007, Spain; SocatriTricastin 2008, France, Krsko 2008, Slovenia) together with a retrospective analysis of the management of uncertainties in Norway after the Chernobyl accident, and a study of citizen science after the Fukushima accident. The aim of this analysis was to elucidate the understanding and response to scientific and social uncertainties in past incidents and accidents, as well as the related ethical issues.

\section{Method: Case studies}

The different case studies of past nuclear and radiological events analysed in this paper varied with respect to their severity, types of challenges they posed, consequences they caused, actors that were involved in the management, and societal response they generated (Tab. 1) (for detailed descriptions of all cases see Oughton et al., 2018). This variety of conditions created a strong base for getting an overview of all the diverse uncertainties that are associated with emergency response.

The methodological framework consisted of three separate methodological approaches: i) case descriptions (document review); ii) media analysis; and iii) semi-structured interviews. In addition, a participatory observation method was used for 
the Fukushima case. The document analysis was applied in all cases, while other approaches were applied only in selected cases (see Tab. 1). The non-systematical document analysis was used to collect relevant information on the cases for the identification of uncertainties and consisted of in-deep analysis of accident reports, scientific articles, conference presentations, parliament questions, press releases, web-pages, etc. The information collected through the document review included chronological recap of the accident, proactive actions applied, communication aspects and others. The media analysis consisted of all published mass media articles related to the case. Interviews were conducted with residents in the area and some local stakeholders with a particular emergency impact. The following questions were used for the analysis: what uncertainties are being reported directly or indirectly, how these uncertainties are expressed and by whom. For each case study, the document analysis included documents published in a period from the emergency until the year 2018. Also the interviews were conducted in 2018. Prior to the interviews, a methodological document was written and a training for interviewers and coders was provided in order to ensure clear and comparable methodological quality and improve data validity and reliability across the analysed case studies.

\section{Results: Identification of uncertainties}

The seven cases span from 1986 to 2017 and vary in degree of severity, impact and response. Nevertheless, some general conclusions and traits can be seen, including a range of different challenges and uncertainties. All cases initially underestimated the potential impact of the accident in terms of the societal impact and communication challenges (including the communication challenges from the Krsko "non-event"). There was clearly a range of technical uncertainties that generated, in turn, societal uncertainties. In the early phases, technical uncertainties included questions about the magnitude and range of the contamination (all cases), but also included measurement uncertainties linked to both environmental monitoring (data and measurement quality, different instrumentation and measurement techniques, etc.) and health monitoring (e.g., thyroid measurements). For the Asco case in Spain and Fleurus in Belgium, the main uncertainty identified related to whether the discharges had been detected off-site. The need for retrospective analysis and modelling added an additional layer to technical uncertainty, for example in the Asco (4 months) and Tricastin (uncertain length of release) cases.

The reporting and interpretation of measurements added another level of uncertainty, including whether ranges or, more commonly (e.g. Fleurus and Halden), maximum measured values were reported. Variability and inhomogeneity of measurements raised challenges in Norway after Chernobyl and Asco, Spain. Documenting undetectable levels of contamination in both workers (Asco) and the public (Fleurus, Asco) was deemed important for reassurance. Fleurus offered thyroid screening to potentially affected populations. In Ascó, around 2000 medical checks were carried out to workers and to school students that visited the plant during the period of the release. Inhabitants from the closest town were also invited to pass medical checks, and no contamination was detected. Public monitoring was also offered in Norway after Chernobyl, as was monitoring of local produce, although here the focus was on documenting low levels rather than undetectable amounts. Data accuracy was deemed to be a crucial element of citizen science measurement initiatives in Fukushima. The tendency was that the public, or at least those that expressed an opinion, wished for more monitoring and health follow-up than had been initially offered by authorities.

The most important communication uncertainties for all cases were delays in providing information to the public, incomplete information and a perceived lack of transparency; the latter only being contradicted by the Krsko case, where nuclear authority showed too much transparency also linked with their misjudgement/misinterpretation of the event. Nearly all cases also revealed problems with uncertainties as to who had responsibilities, and communication pathways. Interestingly, the aftermath of the Tricastin case sparked a successful dialogue and stakeholder engagement initiative, underlining the importance of a pluralistic approach. Likewise, the citizen science initiatives in Fukushima, while not without their own challenges, also offered important alternative mechanisms of public communication and dialogue.

Some degree of contradictory information was seen in all cases, most usually in the communication of health effects (e.g., no expected health effects, but monitoring carried out anyway - Asco, Fleurus, Tricastin, Fukushima), but also linked to food stuff use: farmers can sell their produce, but you should not consume your own (Fleurus) and water use restrictions (Tricastin). Fukushima, Asco and Chernobyl (Norway) also reported differences in expert opinion, particularly on health effects. Media analysis also revealed quite divergent interpretations of risk between experts (no health impact whatsoever) and NGO's (possible serious impacts).

Although all cases highlighted possible societal impacts, these varied from case to case. Tricastin, Asco and Chernobyl/ Norway all highlighted possible impacts on agriculture and farming. Asco and Tricastin also showed concerns for tourism and stigmatisation for the affected areas, Fleurus for the possible lack of medical isotopes, and Fukushima from a wide range of impacts, including stigma. The question of compensation to farmers for losses was quickly raised in Norway and France. The incidents also resulted in important changes in safety protocols and procedures at many of the installations.

There were also differences in societal framing of the cases. The incidents raised questions on acceptability of nuclear energy in Belgium, Spain, France, Slovenia and Japan. In Belgium, a discussion on thyroid monitoring pointed out difficulties with the timing of measurements, given the screening was planned on the first day of school, before teachers and children had bonded. In Norway, the accident coincided with a change in government, which created uncertainties about available resources. Not surprisingly, the citizen monitoring in Fukushima occurred in a complex situation of disruption on family life and breakdown on trust between society, science and authorities.

Ethical aspects of the cases included the focus on vulnerable populations (e.g., high school pupils seen in Asco and Fleurus; and minority cultures seen in Norway/Chernobyl), sensitivity to differences in distribution of exposures and impacts, initiatives to empower and increase control of affected populations and issues with information transparency highlighted above. 
Table 1. Overview of the case studies analysed and the applied method.

\begin{tabular}{|c|c|c|}
\hline Country & Year & Case description \\
\hline Belgium & 2008 & $\begin{array}{l}\text { Accidental release of radioactive iodine from a } \\
\text { facility producing radioisotopes for medical use, } \\
\text { located in Fleurus, Belgium } \\
\text { The release of radioactive iodine occurred during the } \\
\text { waste transfer within the facility. The release went } \\
\text { unnoticed for several days causing delay in } \\
\text { communication. Temporary protective actions directed } \\
\text { at the population with regard to consumption of food } \\
\text { from their own gardens were taken, and medical } \\
\text { examinations of thyroid were offered }\end{array}$ \\
\hline Spain & 2007 & $\begin{array}{l}\text { Accidental release of radioactive particles with } \\
\text { activated corrosion product isotopes from Ascó I } \\
\text { Nuclear Power Plant (NPP) in Tarragona, Spain. } \\
\text { The release was initiated by an operational incident } \\
\text { but went unnoticed for four months. A wide } \\
\text { monitoring program had to be established to check } \\
\text { over } 2700 \text { persons, both workers and visitors that } \\
\text { were at the plant during this period of time, including } \\
\text { a school group }\end{array}$ \\
\hline
\end{tabular}

France $2008 \quad$ Uranium leak in the Socastri plant, carrying out treatments of nuclear effluents coming from the AREVA facilities, at the Tricastin nuclear site Overflow from a storage tank containing uranium effluents caused discharge into the surrounding rivers. Temporary restrictive actions on water use and consumption had to be established. Environmental surveillance programs implemented after the accident clearly showed that there was no persistent pollution linked to the uranium discharge of Socatri factory. However, the results reinforced the presence of former uranium contamination in the groundwater, which was detected by an environmental study already underway and not directly linked with the Socatri incident

Norway

2016

Slovenia

2008

Norway
Iodine release at the research reactor in Halden,

Norway

Unintended release of radioactive iodine occurred during handling of test fuel. There was a 20-hour delay in reporting of the accident to the responsible authorities. The release was small, however, it unleashed a wave of conspiracy articles about a reactor meltdown in Norway several months later

The Unusual Event at the NPP Krško, Slovenia A leakage from the primary system to containment was detected at the Krško nuclear power plant. Investigations showed that the event had no important safety indications and it was classified at level 0 of the INES scale. However, it produced an extreme and enormous response and coverage in the media in almost all EU countries

1986 Retrospective analysis of the decision-making in Norway after the Chernobyl accident Norway was one of the countries outside of the Soviet
INES Method

scale

3

Document analysis, media analysis $\left(N_{a}=361\right)^{\mathrm{a}}$, semi-structured interviews $\left(N_{p}=15\right)^{\mathrm{b}}$
2

1
Document analysis, media analysis $\left(N_{a}=275\right)$, semi-structured interviews $\left(N_{p}=23\right)$

Document analysis, media analysis $\left(N_{a}=34\right)$

$$
\begin{aligned}
& \text { Document analysis, media analysis } \\
& \left(N_{a}=46\right)
\end{aligned}
$$

Document analysis, media analysis $\left(N_{a}=207\right)$.

\section{Document analysis}


Table 1. (continued).

\begin{tabular}{|c|c|c|c|c|}
\hline Country & Year & Case description & $\begin{array}{l}\text { INES } \\
\text { scale }\end{array}$ & Method \\
\hline & & $\begin{array}{l}\text { Union that was heavily contaminated by the } \\
\text { Chernobyl accident. Norway had no nuclear } \\
\text { preparedness system at the time. There was confusion } \\
\text { regarding who is responsible for handling the } \\
\text { response and lack of coordination between the } \\
\text { different actors which led to delays in communication } \\
\text { and information to the population. A range of } \\
\text { countermeasures had to be implemented in the food } \\
\text { production chain }\end{array}$ & & \\
\hline Japan & 2011 & $\begin{array}{l}\text { A study of citizen science in Japan after the } \\
\text { Fukushima accident } \\
\text { In the wake of the accident, networks of citizens } \\
\text { measuring radiation were established. This case } \\
\text { analysed to what extent bottom-up engagement can } \\
\text { help to cope with scientific and social uncertainties }\end{array}$ & 7 & $\begin{array}{l}\text { Document analysis, semi-structured } \\
\text { interviews }\left(N_{p}=12\right) \text {, and participatory } \\
\text { observation ( } 6 \text { weeks) }\end{array}$ \\
\hline
\end{tabular}

\footnotetext{
${ }^{a} \mathrm{~N}_{\mathrm{a}}$ - number of newspaper articles analysed.

b $\mathrm{N}_{\mathrm{p}}$-number of persons interviewed.
}

\section{Conclusions}

The aim of this study was to provide a first, preliminary identification of different uncertainties associated with emergency response from a societal, communication and ethical perspective. Importantly, the types of uncertainties uncovered showed that emergency preparedness needs to address more than technical and model uncertainties, and recognise that social and ethical uncertainties also relate to the actions and concerns of the public and other involved actors (see French et al., 2020). This means that uncertainties need to be described not only in technical terms - such as error ranges and variabilities, but also value implications (e.g., how much uncertainty is acceptable) and societal consequences (e.g., who will be impacted if the assessments are wrong). The characterisation of different uncertainties and their interconnection was further refined through other activities in CONFIDENCE WP5. This included investigations of:

- lay persons and emergency actors' understanding and processing of uncertain information, and subsequent behaviour, in nuclear emergency situations (Turcanu et al., 2018);

- societal uncertainties and ethical issues in emergency and post-accident situations, from the early phase to recovery (Perko et al., 2019b);

- mental models of risk (Zeleznik et al., 2020) and;

- improved tools for communication of uncertainties, specifically for low radiation doses (Perko et al., 2019a; Perko et al., 2020).

Acknowledgement. The work described in this paper was conducted within the CONFIDENCE project which was part of the CONCERT project. This project has received funding from the Euratom research and training programme
2014-2018 under grant agreement No.662287. This work was also partly supported by the Research Council of Norway (RCN) (Grant Number 223268/F50 [CERAD-Centre for Environmental Radioactivity] and Grant Number 263856/E40).

Disclaimer (Art. 29.5 GA). This publication reflects only the author's view. Responsibility for the information and views expressed therein lies entirely with the authors. The European Commission is not responsible for any use that may be made of the information it contains.

\section{References}

Charron S, Lafage S, van Asselt E, Baptista M, van Bourgondiën M, Brandhoff P, Cabianca T, Camps J, Cessac B, Crouail P, Durand V, Gallego E, Gil O, Holmes S, Hourdakis C, Jones K, Kamenopoulou V, Lecomte JF, Liland A, Lopes I, Madruga MJ, Martins JO, Mc Mahon C, Montero M, MurithC, Olyslaegers G, Organo C, Paiva I, Peltonen T, Portugal L, Potiriadis C, Prades A, Reis M, Rossignol N, Schneider T, Sala R, Smith V, Tafili V, Teles P, Tomkiv Y, Trueba C, Turcanu C, Turtiainen T, Twenhöfel C, Vaz P. 2016. Overview of the PREPARE WP3: Management of contaminated goods in post-accidental situation-Synthesis of European stakeholders' panels. Radioprotection 51: S83-S91.

Felt U, Chhem RK. 2016. Techno-natural disaster and the role of expertise. In: Health in disasters. A science and technology studies practicum for medical students and healthcare professionals (R.K. Chhem, G. Clancey, Eds.). Fukushima, Japan: Fukushima Medical University.

French S, Haywood S, Oughton DH, Turcanu C. 2020. Different types of uncertainty. Radioprotection 55(HS1). https://doi.org/10.1051/ radiopro/2020029.

Leonard HB, Howitt AM. 2008. "Routine" or "crisis"- the search for excellence. Crisis Response 4(3): 32-35.

Marignac Y, Hazemann J, Baudé SJR. 2016. Managing the complexity of societal needs in a nuclear emergency situation: 
Towards further experts collaboration for the "enlightened protection" of populations. Radioprotection 51: S159-S161.

Oughton DH, Perko T, Abelshausen B, Kenens J, Van Oudheusden M, Turcanu C, Sala R, Oltra C, Tomkiv Y, Maître M, Schneider T, Zeleznik N. 2018. Case descriptions for characterization and response to uncertainty in past nuclear emergencies. CONCERT Deliverable D9.25. Available from https://www.concert-h2020. eu/en/Publications.

Perko T, Benighaus L, Tafili V, Oughton DH, Tomkiv Y, Sala R, Germán S, López S, Oltra C, Duranova T, Raskob W, Müller T, Nishizawa M, Wolf HV, Thijssen P, Camps J, Turcanu C, Benighaus C, Moschner J, Renn O. 2019a. Guidelines on tools for communication of uncertainties. CONCERT Deliverable D9.29. Available from https://www.concert-h2020.eu/en/Publications.

Perko T, Tafili V, Sala R, Duranova T, Zeleznik N, Tomkiv Y, Hoti F, Turcanu C. 2019b. Report on observational study of emergency exercises: List of uncertainties. CONCERT Deliverable D9.28. Available from: https://www.concert-h2020.eu/en/Publications.

Perko T, Benighaus L, Tomkiv Y, Wolf HV. 2020. Guidance on communicating about uncertainties in nuclear emergency management. Radioprotection 55(HS1). https://doi.org/10.1051/ radiopro/2020028.

Schmid SD. 2013. Nuclear emergency response: Atomic priests or an international SWAT team? In: Nuclear disaster at Fukushima Daiichi: Social, political and environmental issues (R. Hindmarsh, Ed.), pp. 194-213. New York: Routledge.

Turcanu C, Perko T, Abelshausen B, Oltra C, Sala R, Tomkiv Y, Oughton DH, Liland A, Zeleznik N. 2018. Planned behaviour in nuclear emergency situations. CONCERT Deliverable D9.26. Available from https://www.concert-h2020.eu/en/Publications.

Turcanu C, Perko T, Baudé S, Hériard-Dubreuil G, Oughton DH, Tomkiv Y, Sala R, Oltra C, Tafili V, Benighaus L, Maitre M, Schneider T, Crouail P, Duranova T, Paiva I. 2020. Social, ethical and communication aspects of uncertainty management. Radioprotection 55(HS1). https://doi.org/10.1051/radiopro/ 2020024.

Zeleznik N, Benighaus L, Mitrakos D, Tafili V, Duranova T, Sala R, Benighaus C. 2020. Mental models in nuclear emergency management. Radioprotection 55(HS1). https://doi.org/10.1051/ radiopro/2020026.

Cite this article as: Tomkiv Y, Perko T, Sala R, Zeleznik N, Maitre M, Schneider T, Oughton DH. 2020. Societal uncertainties recognised in recent nuclear and radiological emergencies. Radioprotection 55(HS1): S151-S155 